\title{
Driver's Visual Engagement in Urban Streetscape
}

\author{
Lanta Kautsar Akromi, Bambang Soemardiono and Purwanita Setijanti \\ Department of Architecture, Institut Teknologi Sepuluh Nopember, Surabaya \\ e-mail:lantaakautsar@gmail.com
}

\begin{abstract}
Abstrak-Representation of visual engagement in urban street through the streetscape is an important in urban design research as a city framework. Urban street are composed of various classifications and attract more attention from townspeople. Visual engagement is an important component for understanding a city. Human's perception of the nature environment and build environment gives a difference feeling to the visual. The city formed by many urban street that forms it. However, the establishment of this street still does not pay attention to the interests about visual on the street system as a city frameworks, but only pay attention to the function of the street. Urban street have regulations related to speed limits that are affect the visual of the driver. The importance of visual engagement driver's when through the street to understanding of the city. The methodology in this study uses a post-positivist paradigm with quantitative strategies. Data collection tactics using Likert scale questionnaires was given to drivers or people who through the street by car with intensity once a week and data analysis uses SPSS application with descriptive statistics to identify factors that the most affect. The results of this study are to identify the factors of the urban streetscape that the most affect to the drivers when through the street. The visual elements factor that include the mass of the building, building entrance, textures, colours, and materials was establish the enclosure space on the street corridor. from these results identified a new factors that affect to visual engagement drivers.
\end{abstract}

Keywords-Nature and Built Environment, Sttreetscape, Visual Engagement.

\section{INTRODUCTION}

$\mathrm{T}$ HERE are two types of nature environment and built environment [1]. Human perception of nature environment and built environment gives a difference sensing in visual. Visual engagement representation on urban street through streetscape is an important idea in urban research. Selecting the relevant item on the field of view and allowing it to appear on the human visual gives a better perception of details and elements [2]. The visual perception on the streets of the city is distinctive and easy to attract visual attention and is recognized by the human mind [3]. The visual engagement representation on streetscape is very important because everyone experiences the city through the street other than streetscape is one element in the outer space that is important in the formation the city's character, The visual character of a city is formed from streetscape visual elements that form directly the urban image [4-5]. Therefore we can see that the urban streetscape was an important role in the development of urban life [6]. From the perspective of the street as a city framework, urban street attrac more attention from the townspeople [7-8]. But the streets is still not concerned about the importance, only pay attention to the functions of the street as well as the regularization of the street to give difficulties for people to distinguish visual and understand a city as a framework [10-11]. The role of the street users to the existence of urban street that make the character and image of the city is still visible [12]

In designing a space or the face of a street's spatial and physical materiality, with the qualities and facilities it affects the user's street experience in a region [9]. These visual experiences are a visual engagement to the stakeholders, in which the study is a drivers or people who through the streeta by car. Visual engagement occurs because there are interesting and dynamic visual characters that can be achieved through a continuous view or continual termination [12]. Visual engagement is formed from a visual character that is an image of perceived perception with the eye [13]. Visual characters in a city are formed from visual elements in street corridor consisting of a physical element of a view to be recorded in a person's observation including; Path, Degree of Enclosure, Architectural Pattren, Activity Pattern, Street trees [15]. This research will be engage on the Jalan Mayjen Sungkono Surabaya, classified as a secondary artery street with regulation of speed limit between $40-60 \mathrm{~km} / \mathrm{h}$. RTDR Surabaya 2014-2034 [16]. The importance of visual engagement to the drivers is provide an understanding the city by streets, and increasing the safety drivers and other street users.

\section{METHOD}

The methodology in this study uses quantitative research methods [17]. The tactics of data analysis using SPSS and descriptive analysis. Data collection tactics using closed questionnaire with Purposive non probability sampling and accidental sampling. This tactic takes the respondent as a sample based on anyone who is coincidentally encountered and is considered able as a respondent. The questionnaire is distributed to the drivers or people who is through the streets by car with intesity once a week. The questionnaire contains a research variables between the streetscape variables and the visual element variables in the street. The results of the questionnaire were performed data correlation and factor analysis to find a new factors that gave visual engagement to the drivers through the streets.

\section{OVERVIEW}

Mayjend Sungkono Street, is a municipality street that managed by Surabaya city Government, the landuse for commerce and services dominated by Highress Building and Commerce Building with length of $\pm 2 \mathrm{Km}$, and consist of two lanes with a boulevard as a median, has a width of $6 \mathrm{~m}$ on both sides it can accommodate up to 3 rows of cars with 
The $6^{\text {th }}$ International Seminar on Science and Technology (ISST) 2020

July $25^{\text {th }}, 2020$, Institut Teknologi Sepuluh Nopember, Surabaya, Indonesia

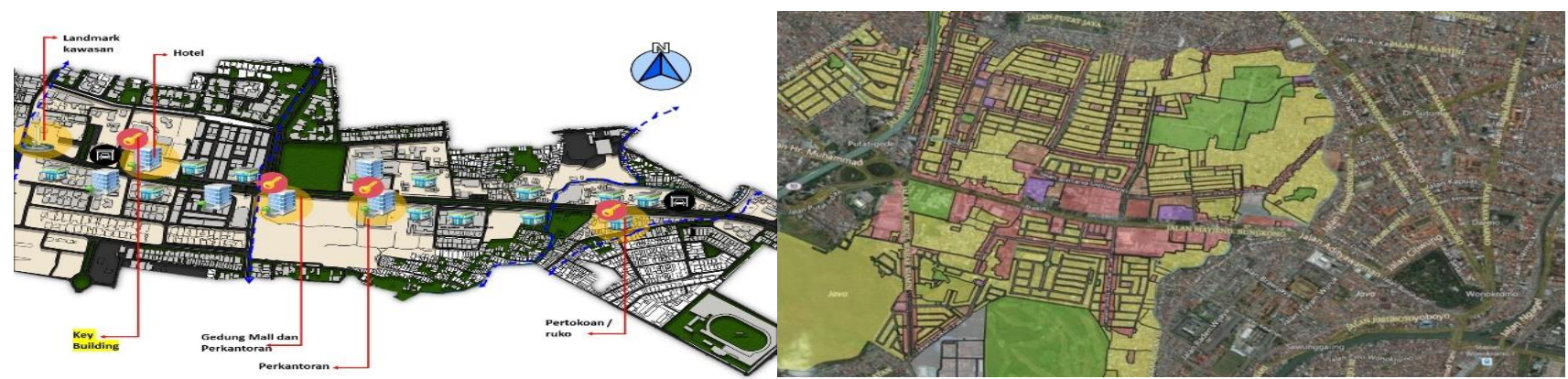

Figure 1. Landuse and Site of Mayjen Sungkono Street.
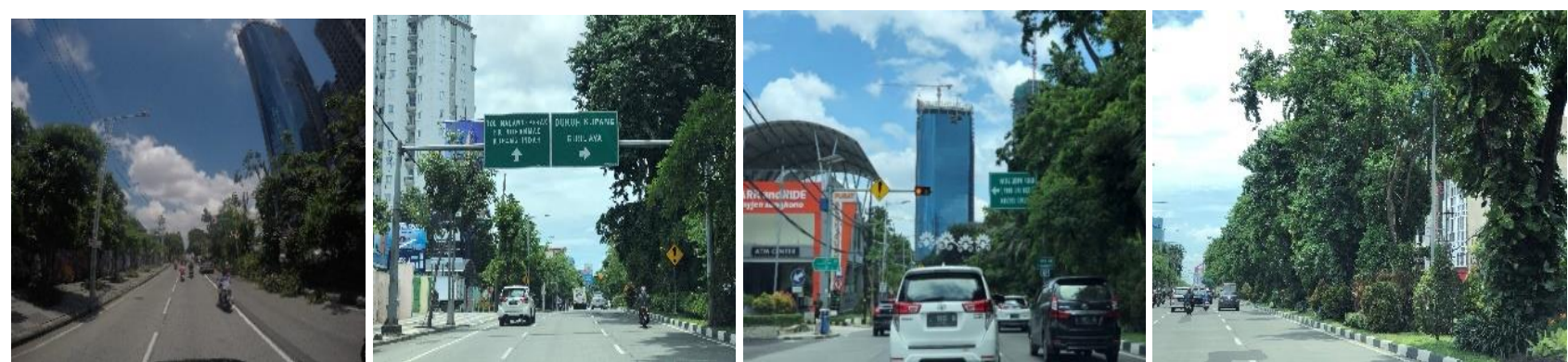

Figure 2. Existing of Mayjen Sungkono Streetscape.

Table 1.

Respondent's Education

\begin{tabular}{lrrrr}
\hline \hline & Frequency & Percent & Valid Percent & Cumulative Percent \\
\hline High School & 22 & 22.0 & 22.0 & 22.0 \\
Bachelor Degree & 68 & 68.0 & 68.0 & 90.0 \\
Master Degree & 9 & 9.0 & 9.0 & 90.0 \\
Doctoral Degree & 1 & 1.0 & 1.0 & 100.0 \\
Total & 100 & 100.0 & 100.0 & \\
\hline \hline
\end{tabular}

Table 2.

Respondent's Origin

\begin{tabular}{llrrrr}
\hline \hline & Frequency & Percent & Valid Percent & Cumulative Percent \\
\hline Surabaya & 76 & 76.0 & 76.0 & 76.0 \\
$\begin{array}{l}\text { Outside Surabaya } \\
\text { Total }\end{array}$ & 24 & 24.0 & 24.0 & 100.0 \\
\hline \hline
\end{tabular}

linear circulation type and average speed limit on the street is 40-60 Km/Hour. Landuse and Site of Mayjen Sungkono street can see Figure 1 and Existing of Mayjen Sungkono streetscape can see Figure 2.

\section{RESULT AND DISCUSION}

The results of this study consist of respondent data and the analysis factors of the questionnaire that had been distributed to the drivers based on the respondent data consists of the respondent's education, respondent's origin and respondent's intensity, Respondent data used to classify regarding the understanding of the questionnaire question and understanding of the location by looking at the results of intensity during the way. Respondent's data are discusses the respondents'

\section{A. Sample Determination}

The sampling of the samples in this study used Purposive non probability sampling with the tactics of Convenience anncidental random sampling. Sampling is based on the fact that those people who through the street by car with the intensity at least once a week, and based on who is accidentally encountered and considered suitable as a respondents.

$$
n=\left[\frac{Z \frac{1}{2} \alpha}{E}\right]^{2}
$$

$$
n=\left[\frac{1,96 \cdot 0,25}{0,05}\right]^{2}=96,04
$$

\section{Description:}

$\mathrm{n}=$ Number of samples

$\mathrm{Z}^{1 / 2} \mathbf{2}=$ Sample Normal Distribution Table- 95\% (Accuracy level) $=1,96$

\section{$\alpha=$ Sample Error- $25 \%$ \\ $\mathrm{E}=$ Error of Estimate $(5 \%-20 \%)$}

In this study a tolerable fault limit was $5 \%$ so that the accuracy level sample was $95 \%$ (1.96). From the calculation result using the formula, obtained the number of samples to be taken into part of the research is 96.04 (rounded 100 respondents). 
The $6^{\text {th }}$ International Seminar on Science and Technology (ISST) 2020

July $25^{\text {th }}, 2020$, Institut Teknologi Sepuluh Nopember, Surabaya, Indonesia

Table 3.

Respondent's Intensity

\begin{tabular}{|c|c|c|c|c|}
\hline & Frequency & Percent & Valid Percent & Cumulative Percent \\
\hline 1 time & 48 & 48.0 & 48.0 & 48.0 \\
\hline 2 time & 17 & 17.0 & 17.0 & 65.0 \\
\hline More than 3 times & 30 & 30.0 & 30.0 & 95.0 \\
\hline Every day & 5 & 5.0 & 5.0 & 100.0 \\
\hline Total & 100 & 100.0 & 100.0 & \\
\hline
\end{tabular}

Table 4.

Variables Data Research

\begin{tabular}{llll}
\hline \hline & Streetscape & & Visual Street Corridor \\
\hline Variable & Sub-Variabel & Variable & Sub-Variabel \\
\hline Streetscape & Variable Pedestrian & Path & Variable Street width \\
& Variable Street Furniture & & Variable Median \\
& Variable Signage & Variable 1 Street height \\
& Variable Circulation & Degree of enclosure & Variable Mass Building \\
& Variable Parking Area & Streettrees & Variable Vegetation \\
& Variable Open Space & Architectural Pattern & Variable Entrance Building \\
& Variable Dead Space & Variable Facade Building \\
& Variable Electric Pole & Variable Street and building materials \\
& & Variable Texture of street and buildings \\
& & Variable Building pattern \\
& & Variable Facade Color Building \\
& & Variable Activity Support \\
\hline \hline
\end{tabular}

Table 5 .

Validity Test Data

\begin{tabular}{|c|c|c|c|}
\hline Variable & r_Number & r_Table & Results \\
\hline Variable Pedestrian & 0,665 & 0,195 & Valid \\
\hline Variable Street Furniture & 0,697 & 0,195 & Valid \\
\hline Variable Signage & 0,612 & 0,195 & Valid \\
\hline Variable Circulation & 0,605 & 0,195 & Valid \\
\hline Variable Parking Area & 0,328 & 0,195 & Valid \\
\hline Variable Open Space & 0,300 & 0,195 & Valid \\
\hline Variable Dead Space & 0,699 & 0,195 & Valid \\
\hline Variable Electric Pole & 0,333 & 0,195 & Valid \\
\hline Variable Pedestrian & 0,630 & 0,195 & Valid \\
\hline Variable Street width & 0,653 & 0,195 & Valid \\
\hline Variable Median & 0,644 & 0,195 & Valid \\
\hline Variable 1 Street height & 0,535 & 0,195 & Valid \\
\hline Variable Mass Building & 0,638 & 0,195 & Valid \\
\hline Variable Vegetation & 0,618 & 0,195 & Valid \\
\hline Variable Entrance Building & 0,631 & 0,195 & Valid \\
\hline Variable Facade Building & 0,653 & 0,195 & Valid \\
\hline Variable Street and building materials & 0,580 & 0,195 & Valid \\
\hline Variable Texture of street and buildings & 0,648 & 0,195 & Valid \\
\hline Variable Building pattern & 0,646 & 0,195 & Valid \\
\hline Variable Facade Color Building & 0,672 & 0,195 & Valid \\
\hline
\end{tabular}

\section{B. Discussing Respondent's Data}

The respondent's Data discusses the demographic of respondents covering the whole community or specific groups, which are based on the criteria; respondent's education, respondent's origin, and respondent's intensity.

Based on the results of the questionnaire data the respondent's education (Table 1) level of respondents with a value of more than $50 \%$ have an education level Bachelor Degree. Education Data used to determine the level of understanding of the Questionnaires. The results can be categorized that all respondents can understand the context of the questionnaire because they have a high level of education.

Based on the results of the questionnaire data the respondent's origin (Table 2) with more than $50 \%$ of the respondents lives in the city of Surabaya. The respondent's lives data is used to determine the level of understanding of the research site. Based on the results of the questionnaire data the respondent's Intensity data (Table 3) is used to determine the intensity of respondents through the street by car atleast once a week, the results are almost a halfrespondents have through the street even only once a week with $48 \%$, and $30 \%$ more than 3 times in a week.

From the respondent data can be concluded that the majority of respondents are at bachelor degree and lives in the city of Surabaya with the intensity through the street once a week. The result of data can be concluded that the respondents understand the context of questionnaires.

\section{Discussing Factor Analysis}

The factor analysis discusses about finding factors that affect the visual engagement of drivers. Analysis factors test the vaidity, reability, and finding of new factors from several existing factors. Factor analysis is the result of the correlation of two large variables along with its sub-factors to generate new factors. Variables data research can see Table 4. 
The $6^{\text {th }}$ International Seminar on Science and Technology (ISST) 2020

July $25^{\text {th }}, 2020$, Institut Teknologi Sepuluh Nopember, Surabaya, Indonesia

Table 6.

Reliability Test Data

\begin{tabular}{lllll}
\hline \hline Variable & \multicolumn{2}{c}{ Nilai Cronbach's alpha (a) } & Number of items & Description \\
\hline $\begin{array}{c}\text { Streetscape } \\
\begin{array}{l}\text { Visual pada koridor } \\
\text { jalan }\end{array}\end{array}$ & 0,755 & 9,884 & 11 & Reliabel \\
\hline \hline
\end{tabular}

Table 7.

KMO test and bartlett's Tes Data

KMO and Bartlett's Test

Kaiser-Meyer-Olkin Measure of Sampling Adequacy.

\begin{tabular}{|c|c|c|c|c|c|c|}
\hline \multirow{2}{*}{\multicolumn{2}{|c|}{ Bartlett's Test of Sphericity }} & & \multirow{2}{*}{$\begin{array}{r}\mathbf{. 0 5 0} \\
1087.689 \\
190 \\
.000 \\
\end{array}$} \\
\hline & & & & & & \\
\hline \multicolumn{7}{|c|}{$\begin{array}{c}\text { Table } 8 . \\
\text { Total Variance Expalined Analysis Data }\end{array}$} \\
\hline \multicolumn{7}{|c|}{$\begin{array}{r}\text { Total Variance Explained } \\
\end{array}$} \\
\hline & \multicolumn{3}{|c|}{ Initial Eigenvalues } & \multicolumn{3}{|c|}{ Extraction Sums of Squared Loadings } \\
\hline Component & Total & \% of Variance & Cumulative \% & Total & \% of Variance & Cumulative \% \\
\hline 1 & 7.550 & 37.751 & 37.751 & 7.550 & 37.751 & 37.751 \\
\hline 2 & 2.229 & 11.147 & 48.898 & 2.229 & 11.147 & 48.898 \\
\hline 3 & 2.042 & 10.212 & 59.109 & 2.042 & 10.212 & 59.109 \\
\hline 4 & 1.193 & 5.964 & 65.074 & 1.193 & 5.964 & 65.074 \\
\hline 5 & .895 & 4.473 & 69.547 & & & \\
\hline 6 & .804 & 4.018 & 73.565 & & & \\
\hline 7 & 699 & 3.494 & 77.059 & & & \\
\hline 8 & .633 & 3.166 & 80.224 & & & \\
\hline 9 & .597 & 2.987 & 83.211 & & & \\
\hline 10 & .500 & 2.500 & 85.711 & & & \\
\hline 11 & .463 & 2.313 & 88.024 & & & \\
\hline 12 & .437 & 2.185 & 90.210 & & & \\
\hline 13 & .361 & 1.803 & 92.013 & & & \\
\hline 14 & .331 & 1.656 & 93.669 & & & \\
\hline 15 & .300 & 1.499 & 95.169 & & & \\
\hline 16 & .252 & 1.258 & 96.427 & & & \\
\hline 17 & .227 & 1.133 & 97.560 & & & \\
\hline 18 & .176 & .882 & 98.442 & & & \\
\hline 19 & .163 & .814 & 99.256 & & & \\
\hline 20 & .149 & .744 & 100.000 & & & \\
\hline
\end{tabular}

\section{Validity Test}

The validity test is to correlate the visual element variables in the road corridor. the result of the r_Number on each variable will be compared to the table r_Value of Streetscape elements with a significant level of 5\% if $\mathrm{r} \_$Number more than $r_{-}$Tables, then the variable is declared valid, and can be continued to the next stage. Based on the results of the data in the table 5 is known that all sub-variables are declared valid. Because As the correlation value $r_{-}$Number the whole variables has a number greater than the $r_{-}$Tabel. The resulting data is valid and can continue to the next stage.

\section{E. Reliability Test}

Based on the results of the data in the table 6 that both of the main sub-variables, reliability test to see the consistency of the questionnaire with the same respondent's data and obtained a value of more than 0.6 then declared reliable and can be continued to the next stage.

\section{F. KMO Test and Bartlett's Test}

At this stage is determining the value Of Kaiser-MayerOlkin (KMO) Measure of Sampling adequancy. The size of
KMO value is used to measure the adequacy of samples by comparing with the correlation coefficient observed with the partial correlation coefficient. Based on the results of the data in the table 7 it is known that the value is 0.858 and exceeds the 0.5 limit. While the significance of 0.000 that explains that this variable forming factor is good and can be continue to the next stage.

\section{G. Total Variance Expalined Analysis}

The results of the data analysis formed as many as 4 factors. These factors are formed because they have a value of Initial Eigvalues more than 1.00. The number of Eigvalues under 1 is not used in calculating. A cumulative percentage of 65.074 from that number will explain $65.074 \%$ of the variability of the original variables and can be continued to the next stage.

Based on the results of data in the table 8 is known that formed 4 factors. These factors are formed because they have a value of Initial eigvalues of more than 1.00, while numbers below 1.00 are not used to calculate the number of factors. A No factor is formed, acumulative percentage of 65.074 of that number will explain $65.074 \%$ of the variability of the original variables and can be continued to the next stage. 
The $6^{\text {th }}$ International Seminar on Science and Technology (ISST) 2020

July $25^{\text {th }}, 2020$, Institut Teknologi Sepuluh Nopember, Surabaya, Indonesia

Table 9.

Rolated Component Matrix Analysis Data

\begin{tabular}{|c|c|c|c|c|}
\hline \multicolumn{5}{|c|}{ Rotated Component Matrix ${ }^{\mathrm{a}}$} \\
\hline & \multicolumn{4}{|c|}{ Component } \\
\hline & 1 & 2 & 3 & 4 \\
\hline Variable Pedestrian & .261 & .553 & .476 & -.032 \\
\hline Variable Street Furniture & .174 & 610 & .495 & .116 \\
\hline Variable Signage & .119 & .531 & .494 & .037 \\
\hline Variable Circulation & .246 & .252 & .712 & -.010 \\
\hline Variable Parking Area & .108 & -.263 & .398 & .621 \\
\hline Variable Open Space & -.011 & .100 & -.100 & .837 \\
\hline Variable Dead Space & .248 & .801 & .170 & .065 \\
\hline Variable Electric Pole & .019 & .079 & -.029 & .838 \\
\hline Variable Pedestrian & .248 & .465 & .158 & .436 \\
\hline Variable Street width & .179 & .742 & .179 & .128 \\
\hline Variable Median & .171 & .878 & .092 & .002 \\
\hline Variable Street height & .066 & .305 & .733 & -.081 \\
\hline Variable Mass Building & .573 & .320 & .204 & .051 \\
\hline Variable Vegetation & .370 & .637 & .264 & -.273 \\
\hline Variable Entrance Building & .802 & .194 & .166 & -.088 \\
\hline Variable Facade Building & .385 & .124 & .566 & .310 \\
\hline Variable Street and building materials & .766 & .101 & .193 & -.079 \\
\hline Variable Texture of street and buildings & .803 & .154 & .069 & .166 \\
\hline Variable Building pattern & .840 & .154 & .106 & 056 \\
\hline Variable Facade Color Building & .765 & .238 & .097 & .143 \\
\hline
\end{tabular}

Table 10.

Factors Naming

\begin{tabular}{lll}
\hline \hline Factor & Sub-Variable Name & Factor name \\
\hline 1 & Mass Building & Visual elements \\
& Entrance building & \\
& Street Material and building facades & \\
& Street texture and façade building & \\
& Building Pattern Form & \\
& Color facade Building & \\
& Pedestrian & Street geometry \\
& Street Furniture & \\
Sigane & Open Space & \\
& Power pole & \\
& Width path & \\
& Median Street & \\
& Vegetation & \\
& Circulation & Visibility \\
& Street Height & \\
& Facade Buildings & Outdoor Space Activities \\
& Parking Area & \\
& Activity Support & \\
\hline \hline
\end{tabular}

\section{H. Rolate Component Matrix Analysis}

In the results of data rotated component matrix indicates that the value of more than 0.5 to a sub factor of the 4 new factors, when in the sort from number 1 to the right, the factors that affect the most and some of its subfactors.

Based on the results of data in the table 9 and tablle 10 is known that formed as many as 4 new factors. 4 new big factors. The grouping of these variables is formed due to the similarity of identical data traits or characteristics between variables one and other variables [19]. Architectural pattern that can be concluded a factor that affect the visual engagement of the drivers with the intensity of the respondents while through the street at least one times a week as much as $48 \%$ which is the visual element factor in the street corridor consist of the sub-period of the building mass, Building entrance, material, colour and texture of the road and the façade [18].

\section{CONCLUSION}

Mayjen Sungkono street is urban street which pay more attention from drivers, because it easily attract visual attention by the human mind. Visual engagement factors that most attract the driver are consist of building mass, building entrance, material, texture, form and colour are variables to be identified in urban streetscape. they forming an enclosure in the corridors thus provides a visual series view or continues image view and feeling to the drivers at the same time understanding a city and also increasing the safety to the other streets user. [18] [13].

\section{DAFTAR PUSTAKA}

[1] Altman Irwin, J. F. W. (2012) Behavior and the Natural Environment.

[2] Lemonnier, S. et al. (2020) 'Drivers' visual attention: A field study at intersections', Transportation Research Part F: Traffic Psychology and 
The $6^{\text {th }}$ International Seminar on Science and Technology (ISST) 2020

July $25^{\text {th }}, 2020$, Institut Teknologi Sepuluh Nopember, Surabaya, Indonesia

Behaviour. Elsevier Ltd, 69, pp. 206-221. doi: 10.1016/j.trf.2020.01.012.

[3] Tomko, M., Winter, S. and Claramunt, C. (2008) 'Experientia hierarchies of streets', Computers, Environment and Urban Systems, 32(1), pp. 41-52. doi: 10.1016/j.compenvurbsys.2007.03.003.

[4] Daley, M. R. (2003) 'Streetscape Guidelines for the City of Chicago Streetscape and Urban Design Program', (November).

[5] Rehan, R. M. (2013) 'Sustainable streetscape as an effective tool in sustainable urban design', HBRC Journal. Housing and Building National Research Center, 9(2), pp. 173-186. doi 10.1016/j.hbrcj.2013.03.001.

[6] Crankshaw, M. ; C. (2010) 'Creating Vibrant Public Spaces: Streetscape Design in Commercial and Historic Districts', Journal of Urban Design, 15(2), pp. 287-289. doi: 10.1080/13574801003638103.

[7] Kevin Lynch (1960) The Image Of The City.

[8] Zhen, W. et al. (2020) 'Capturing what human eyes perceive: A visual hierarchy generation approach to emulating saliency-based visual attention for grid-like urban street networks', Computers, Environment and Urban Systems. Elsevier, 80(December 2019), p. 101454. doi: 10.1016/j.compenvurbsys.2019.101454.

[9] Jacobs, J. (2001) Center For The Living City. New York.

[10] Cliff Moughtin, Rafael Cuesta, Christine Sarris, P. S. (2003) Urban Design Method and Technique (Second Edition).
[11] Lemonnier, S. et al. (2020) 'Drivers' visual attention: A field study at intersections', Transportation Research Part F: Traffic Psychology and Behaviour. Elsevier Ltd, 69, pp. 206-221. doi: 10.1016/j.trf.2020.01.012.

[12] Hartanti, N. B. (2014) 'Karakter streetscape sebagai pembentuk identitas kota bogor', (2).

[13] Cullen, G. (1995) The Concise Townscape.

[14] Ching, F. D. (2008) Arsitektur (Bentuk, Ruang dan Tatanan).

[15] Smardon, R. C. (2016) 'Visual Impact Assessment: Where Have We Come from and Where Are We Going?', Journal of Environmental Protection, 07(10), pp. 1333- 1341. doi: 10.4236/jep.2016.710116.

[16] Surabaya, P. K. (2014) RENCANA TATA RUANG WILAYAH KOTA SURABAYA TAHUN 2014-2034.

[17] Linda N Groat; David Wang (2013) Architectural research methods [electronic resource].

[18] Gobster, P. H. and Smardon, R. C. (2018) 'Visual resource stewardship conference proceedings : Landscape and Seascape Management in a Time of Change', (December). doi: 10.2737/NRS-GTR-P-183.

[19] Baroroh, A. (2008) Trik-Trik Analisis Statistik dengan SPSS. 